\title{
THE INSTITUTIONAL PERSONA: WHEN THEATRES BECOME PERSONAS AND THE CASE OF BRISTOL OLD VIC
}

\author{
KIRSTY SEDGMAN
}

\begin{abstract}
This article proposes a definition and terminology for identifying and analysing a concept of institutional persona in relation to theatre. The essay posits the theatre institution as an example of a 'composite persona', whereby cultural value is produced through the interplay between theatre as building, theatre as organisation, and theatre as event. Using the case-study of Bristol Old Vic, I examine how executives and practitioners involved in a specific historic theatre ensured its post-war survival in the 1940s by connecting the prestigious heritage of a local landmark with the national reputation of two London-based organisations. I suggest that theatre institutions offer a particularly rich investigative ground for the application of persona study theory in their need to mobilise individual and organisational personas for the purposes of reinventing a 'good story' and brand over time.
\end{abstract}

\section{KEY WORDS}

Live Performance; Audience; Cultural Value; The Archive; Reputation; Composite Persona

\section{INTRODUCTION}

In this article I examine how institutions and the individuals who work in them engage in acts of persona creation. Attracting their own distinct fandoms (and antagonisms) over time, a cultural institution like a theatre building survives through the construction and maintenance of a distinct 'strategic mask of identity': a public face that is both personalised and cohesive (Marshall \& Barbour 2015). Produced through shifting social relations, it is these masks of identity that shape how people - in varying societal and cultural contexts - understand and make sense of theatre institutions, often in ways that conflict. Here I want to interrogate three key ways in which the term 'institutional persona' tends to be used.

First: where the term 'institutional persona' has been used before, this has often been in reference to buildings. For example, DeHart's research into indigenous development projects in rural Totonicapán describes a visit to San Pedro to see the new community hall: a "large, cement-block, two-story yellow building [which] communicated a formal institutional persona rarely seen in the rural communities at that time" (2009, p. 64). Similarly, Forgan's work on the role of architecture in the formation of the scientific society examines the "demarcation of institutional territory" (1986, p. 91) enacted by impressive building projects, which are used to convey 1) public recognition and 2) prestige. Studying theatre as an institutional persona, though, is to understand how the physical building is only one part of the puzzle. To talk about 'theatre' is sometimes to speak of a theatre building (like the UK's infamous Globe); sometimes 
about a theatre company (from the Royal Shakespeare Company to Complicité); sometimes about the live performance event itself. I therefore propose the theatre institution as a 'composite persona': one whose cultural value comes from the interplay between these varying layers.

Second, the term 'institutional persona' has also been used to refer to the institutionalised persona of the individual within the capitalist workplace, such as teachers (Nao 2011), prison guards (Johnston 2008), 'cancer information specialists' (Hopper et al. 1993), and university professors (McMullen et al. 1996). ${ }^{\mathrm{i}}$ It is therefore essential to consider how the institutional persona as a whole is shaped by its individual personnel. Using the case-study of the Bristol Old Vic, a prominent theatre in the south-west of England, I examine how people involved in this historic theatre asserted its cultural value at key moments of crisis. Bristol Old Vic has seen the value of its eighteenth-century building, the magnificently-preserved Georgian architecture of the Theatre Royal, connected with the value of its organisation from the 1940s: namely the joint management of London's Old Vic theatre company, and the newly-formed Arts Council of Great Britain. Having recently celebrated its $250^{\text {th }}$ anniversary advertising itself as "the longest continuously-running theatre in the English-speaking world" (Bristol Old Vic 2019a), and capitalising again on its Georgian auditorium and prestigious acting heritage to gain both significant media attention and funding, Bristol Old Vic's contemporary image is absolutely the product of its historical reimagining. This article demonstrates how institutions gain both social and economic capital in much the same way as individuals do, through the creation of a persuasive and cohesive narrative of self. In other words: through the production of persona. The 1940s campaign to save the theatre exemplifies Moore et al.'s (2017) analysis of personaconstruction as essentially performative. Here, persona is seen as a public performance of identity that is "neither entirely 'real' nor entirely 'fictional'", but rather connecting together and 'meshing' various characteristics in order to present a cohesive image (2017, p. 4).

Third, certain approaches to persona studies have taken a teleological approach to the institutional persona. This often suggests that it is the rise of the internet - and especially social media - that has given "organisations, brands, institutions and commercial entities" their "public-facing dimension", with "teams of social management operatives conducting licensed online persona management, and a range of employees with quasi-official public selves connected to these identities" (Moore et al. 2017, p. 3). Such analyses tend to be embedded within wider critiques of our contemporary 'consumer culture', in which giant corporations (Holt 2002; Herskovitz \& Crystal 2010), individuals (Peters 1997; Speed et al. 2015), and everything in between are considered implicated in the omnipresent 'branding' exercises inherent to neoliberal capitalism. While the technological innovations of global commodification have indeed afforded institutions unprecedented levels of directness, global reach, and interactive reciprocity (Bucknall and Sedgman 2017), though, it is important to understand that in many ways the institutional persona is not a new phenomenon.

In this article I use Bristol Old Vic as a means to interrogate the idea of the persona of institutions. It is my contention that Bristol Old Vic's institutional persona echoes Marshall's acronym 'VARP', standing for value, agency, reputation, and prestige (qtd Moore et al. 2017). For Marshall, the individual public persona is "created with a particular intention" and relies on the interplay between these four connected dimensions (qtd Moore et al., p. 7). What happens, however, if we examine institutions via these same dimensions? This might raise a number of other questions. How do institutions assert their value by constructing a cohesive public-facing self-image? How can the prestige of a beautiful historic building be capitalised upon to give a new organisation a sense of legitimacy? How were these institutional reputations created and managed before the internet? How does the interconnected agency of individual personas shape 
the institutional persona, and how are relations of power negotiated within the composite? I propose that theatre is a useful starting-point for understanding how the institutional persona operates in more located, historically-grounded, and complexly nuanced ways.

\section{What Is AN INSTITUTIONAL PERSONA?}

The question of what an institution is has a long intellectual history, and has been debated in philosophy, sociology, economics, and other fields. As John Searle points out, given this intense interdisciplinary attention, it is curious that "the ontology, the mode of existence, of institutional reality" (2005, p. 1) has not been reconciled long ago: not only by "such foundational figures as Max Weber, Emil Durkheim [sic], Georg Simmel, and Alfred Schutz", but by "the whole Western tradition of discussing political and social institutions that goes back to Aristotle's Politics, if not earlier" (2005, p. 2). Hence, while institutional analysis is as old as "Durkheim's exhortation to study 'social facts as things'”, institutional theory was by 1991 still considered a novel emerging field, "purportedly represent[ing] a distinctive approach to the study of social, economic, and political phenomena" (Powell \& DiMaggio 1991, p. 1), yet lacking critical consensus about what an institution actually is.

For the purposes of this article, the core of these debates is the difference between an 'organisation' and an 'institution'. In her recent article on corporate social responsibility, Sarah Bice (2017) builds on the influential work of early institutional theorists such as Meyer and Rowan (1977), Powell and DiMaggio (1991), and Campbell and Pedersen (2001) to define an institution as a "social order or pattern [...] which is embedded in cultural and historical frameworks [...] [and] is shaped by and shapes cultural norms, but which is not necessarily a product of [...] conscious design" (2017, p. 17). In other words, an institution is the overarching social, political, cultural framework (e.g. a system like Higher Education) while the specific entities (e.g. discrete universities) that operate within that framework are organisations. In this sense, the conception of 'institution' is actually antithetical to the idea of 'persona'. Yet while institutions are apparently not to be understood as "epiphenomena constructed by actors-the cumulative result of individual choice" (Bice 2017, p. 17), the concept of persona is so useful because it describes exactly that: namely, a cohesive, persuasive, public-facing 'strategic mask of identity' that has been purposely constructed by social actors (Marshall \& Barbour 2015).

However, this academic definition of institutions as overarching "sociological phenomena" (Bice 2017, p. 17) rather than a series of discrete organisations poses a problem. As Peter Rogers points out, this problem is the schism such a distinction opens up between sociology scholars and the wider public, who are unlikely to define institutions via this same critical agenda. While academics may generally agree on the nature of institutions "as an arrangement or regulation" that is "widely known and accepted, [...] common-place and assumed, [and that] underwrites social order as an established principle - e.g. a law, custom, usage, or practice" (2017, p. 129), the way people outside academia actually experience institutions tends to be via its "general meaning as an association of people coming together as a group; but more than that, a grouping created for the promotion of some common object or collective outcome" such as "a church, a school, college, reformatory, asylum or even a guild, a bank, a trade union, a corporation, a charity or non-governmental organisation" (Rogers 2017, p. 129).

The danger of ignoring lived reality in favour of "advancing a critical agenda", Rogers suggests, is that "scholars risk exacerbating the emergent comprehension gaps between theory and practice or risk disappearing into a disgruntled irrelevance" (2017, p. 128). By this logic, a university - or, indeed, a theatre - can indeed be studied as an institution. The challenge lies in 
tracking the ways a specific institution as "organisational structure and form" manages its "socially ascribed identity" against the general meanings and affects acquired by "social institutions as social processes indicative of behavioural functions" (Rogers 2017, p. 128): those big, overarching, disorganised concepts of education, religion, or the arts.

In order to understand how audiences engage with theatre as an institution, I argue that we first need to consider the wider practices of performance-making, producing, criticism, and scholarship that collectively support the theatre industry, in the same way that the practices of journalism (Eide \& Siøvaag 2016) or 'entrepreneurship' (Tolbert \& Coles 2018) might be considered an institution. Yet to adopt Rogers' analysis is also to understand that this is likely not what the majority of the theatre-going public imagine when the term 'theatre institution' is used. Indeed, searching for recent news items with the term 'theater institution' or 'theatre institution' sees this phrase used indistinguishably to describe particular theatre buildings whether San Diego's Old Globe Theatre in the USA (Smith 2019), London's Old Vic in England (Thompson 2018), the Theatre Royal in Sydney, Australia (Dexus Property Group 2019), or Romania's I.L. Caragiale National Theater in Bucharest (Romanian Insider 2018) - and nonbuilding-based theatre companies like New York's Shakespeare in the Park (Desta 2017) or Canada's Why Not Theatre (Nestruck 2018). This phrase also throws up references to people such as Andrew Lloyd Webber (Wood 2018) or Billy Ensley (Toppman 2018) as individual theatre institutions. In all these cases, within non-academic parlance the word 'institution' tends to refer to a specific building, company, or person, rather than the overarching social concept.

If "[p]ersona's peculiar value as a term is its ability to help us understand the relationship between the individual and the social" (Marshall \& Barbour 2015, p. 1), then, the value of the term 'institutional persona' is how it articulates the role that specific organisational and architectural structures play within the individual/social relationship. How do particular institutions mediate between audiences and society? And if "persona helps us understand the construction, constitution, and production of the self through identity play and performance [...] in social settings" (Marshall \& Barbour 2015, p. 2), the institutional persona similarly offers a framework for conceptualising how specific organisations negotiate their own "production of the self" (Marshall \& Barbour 2015, p. 2) against the "fantasies, feelings, attitudes" (Lasdun 1977, p. 780) that have over time become attached to particular buildings, to specific theatre companies or practitioners, and to modes of cultural production. Using this term also facilitates analysis of who is doing the work of producing an institution's identity, and how this process is managed. In order to examine these questions I turn now to the Bristol Old Vic.

\section{HOW TO UNDERSTAND THEATRE AS AN INSTITUTIONAL PERSONA?}

The interlocking definitional conflicts between 'institution' as a building (a theatre), an organisation (a theatre company), and a social concept (the theatre industry) came into view when researching the case-study of Bristol Old Vic, a renowned Georgian theatre in the southwest of England. Built in 1766, the building was known as the Theatre Royal until the mid1940s, when it began a gradual name change that has culminated in its current nomenclature: Bristol Old Vic. To study this history is to witness how the theatre's contemporary persona has been formed over time through the shifts and overlaps between the three categories I name above.

The theatre's historical significance within both Bristol and the wider UK has been comprehensively surveyed by Kathleen Barker (1974) in her seminal book The Theatre Royal Bristol 1766-1966. Barker demonstrates how during the first two centuries "in virtually all respects, an evening in King Street [represented] the translation of the London theatre to the 
Bristol stage" (1974, p. 19), with its illustrious history of actors and actor-managers including such grand historical figures as Sarah Siddons, David Garrick, the Kemballs, Henry Irving, Kate and Ellen Terry, the Keans, and William Charles Macready. Drawing attention to theatre's status as a 'social institution', Barker specifically warns against historicising any specific theatre as an

independent static phenomenon, parthenogenetically created. Like the human beings who shape its destiny, [a theatre] is the produce both of its heredity and of its environment; it is influenced by changes in aesthetic taste, in education, in economies, in politics: in short, by every contemporary social movement. (Barker 1974, p. 3)

Reading Barker's book alongside her 1966 pamphlet 'The Theatre Royal, Bristol: Decline and Rebirth, 1834-1943' is to witness how this nexus of influences actively shapes and re-shapes an institution's identity over time. Barker takes us from the early-1700s, when Bristol theatricals were overshadowed by the 'enormous success' of the Bath Company, to the enthusiastic response in 1764 to the 29-year-old celebrity performer William Powell - who then became the theatre's first manager - to the eighteenth-century decline in fortunes resulting from the Napoleonic wars and lingering divisions of civic identity in which Bristol was seen as a city of 'practical tradesmen', its nearby rival Bath one of 'ton and culture' (Barker 1974, p. 78). All this alongside the competitive growth of non-patent London theatres in the early nineteenth century meant that by the end of 1818 the theatre had closed down, its proprietors advertising "for a fresh lessee - or, as 'X.Y.' put it, 'desperate adventurer'” (Barker 1974, p. 88).

That adventurer was William M'Cready, who was barely able to manoeuvre the theatre through an "uncertain political atmosphere" (Barker 1974, p. 104) and the decline of the city's major tourist economies.ii According to Barker, M'Cready only avoided total bankruptcy by leveraging the celebrity of his famous son, William Charles Macready, and finally uniting the Bath and Bristol theatres into one circuit - one in which Bristol, at long last, became the dominant party. However, it was only in the Victorian era that the theatre began once more to prosper, when it was taken over in the 1850s by James Henry Chute (son-in-law of Sarah M'Cready, who in turn had taken over after the death of her husband). Barker attributes Chute's success to his ability to identify personally with "the most influential section of Bristolians, the successful middle-class businessmen". This enabled Chute to reposition the Theatre Royal

not just as the home of a struggling hack company which could only be made respectable by a succession of stars, but as an artistic, and a moral, force of intrinsic value; a company whose productions, while they might be inspired by the best in the metropolitan theatre, would be worth seeing for their own sake. (Barker 1974, p. 136).

The lesson Barker draws from all this? That "Bristol audiences have always needed an object on whom to focus attachment". Whether that was a "manager or actor, from Powell to Dimond to Peter O'Toole and Denis Carey" (1974, p. 126), the theatre's institutional persona has always, of course, been shaped by individuals. This shaping force can be seen particularly clearly by studying a moment of significant change, when the company's contemporary persona as Bristol Old Vic was eventually secured. Having by the 1930s fallen again into hard times, this is when the Theatre Royal was finally reopened under the post-war management of the newly-formed Arts Council of Great Britain (later the Arts Council of England; at that time called CEMA, the Council for the Encouragement of Music and the Arts).

Studying the archival records from this time is to discover a tactical process of identity reconstruction - an imaginative blending of all this history with a modern reputation for (inter)national innovation. It all began in 1935, when Herbert Farjeon, a famous London playwright and critic, stumbled upon the Theatre Royal on a trip to Bristol following a letter 
from a friend, and found it still "in active if not very dignified service" (University of Bristol Theatre Collection 1943). Over the decade that followed, Farjeon ran a national campaign which deliberately mobilised the theatre's heritage in order to "awaken" Bristol citizens to their "responsibility" as the keepers of this historically-significant theatre (UoB Theatre Collection 1935a). It is this process that the final section in this article examines.

\section{How Is a Theatrical Persona Formed?}

In order to whip up support and secure the institution's future, Farjeon created a persistent mythology: claiming the Bristol Theatre Royal to be, variously, a "rare relic", "the only eighteenth-century theatre in the country" (UoB Theatre Collection 1935b), a "precious and neglected heirloom without a parallel anywhere else in the British Isles" (UoB Theatre Collection 1943), and the "oldest theatre in England" (UoB Theatre Collection 1942).

Such superlatives can of course be contested. For example, on their website the York Theatre Royal currently state that "[t]here has been a theatre on this site since 1744, making us the oldest theatre in the UK outside of London" (York Theatre Royal 2019). Here they refer to London's Drury Lane, which was originally built in 1662/3 but then burned down and was rebuilt twice, in 1671/2 and 1809, and so cannot truly claim to be the oldest theatre because the building is not itself the original. But what counts as 'original', given that most theatres - with Bristol Old Vic no exception - have experienced extensive ongoing renovations over the years? Hence the Georgian Theatre Royal in Richmond, North Yorkshire, built in 1788, now sells itself as "the oldest theatre in the country still working as a theatre in its original form" (Georgian Theatre Royal 2019), while the Theatre Royal in Margate - built one year earlier, in 1787 - has called itself the "oldest unrestored theatre in the country" (Kent Online 2007).

This has left Bristol Old Vic today to claim the moniker of the longest-running theatre in the UK (ITV 2017) or, most recently, the longest continuously-running theatre in the Englishspeaking world (Bristol Old Vic 2019a). Yet over its 252-year history the Theatre Royal has been forced to shut temporarily several times: for renovations and fire upgrades, following owners' deaths and funding cuts. So to what extent can a theatre like this really be said to have been operating 'continuously'? That question rather misses the point: which is that when it comes to the institutional persona, the truth of a defining factor like superior longevity is less important than the power of a good story.

In the case of Bristol Old Vic, this is a story about the successful rebranding of a nationally-historical yet geographically-local theatre building. While there is not the space to deal with these issues in detail here, it is worth noting that Bristol's story is echoed in the national post-war emergence of arts funding, whereby ideals of aesthetic quality were imposed on many so-called 'regional' or 'provincial' theatres by the professional London theatre-sphere. That process was catalysed by Farjeon's 1940s ousting of undignified populism - "twice-nightly revues! - That give one (I say it from experience) the cold shivers" (UoB Theatre Collection 1935b) - in favour of performances whose standards (of acting, staging, writing, directing) were deemed a match for the building itself. The process was later solidified at the end of that decade when the theatre was given to the management of London's Old Vic, who worked in tandem with the Arts Council to install there a brand-new repertory company. Renamed "the Bristol Old

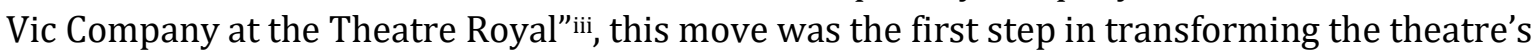
historical identity into the persona we recognise today. This is a persona that has fused the legacy of an important cultural and architectural landmark with the guarantee of forwardthinking aesthetic excellence provided by the combined reputational capital of the Arts Council and Old Vic. 
The Bristol Old Vic archives at the University of Bristol Theatre Collection are full of practitioner anxiety about maintaining excellence: specifically, about the need to ensure that "the standard of the work being done is worthy of support" (UoB Theatre Collection 1946a). As the regional extension of two conjoined London organisations, the Theatre Royal needed now more than ever to "carry forward the work of the Old Vic, and make it worthy of the golden blessing of the Arts Council of Great Britain" (UoB Theatre Collection 1949): an institution which at that time was led by the "[u]nabashedly elitist" John Maynard Keynes, who used his influence to support art that best accorded with traditional ideals of 'high' aesthetic quality (Leventhal 1990, p. 305). In this way, the emergence of Bristol Old Vic's contemporary persona was undeniably bound up in Arnoldian understandings of cultural value - as "the best which has been thought and said in the world" (Arnold 2006, p. 5) - both reflecting and reinforcing dominant systems of aesthetic worth.

That legacy lived on in the efforts of a succession of Directors - Hugh Hunt, Denis Carey, Peter Moody, etc - backed up by the weight of a joint management company featuring its Chairman, Sir Philip Morris (University of Bristol), along with George Chamberlain and John Burrell (London's Old Vic) and Michael MacOwan and Charles Landstone (Director and Assistant Director of the Arts Council of Great Britain). With the Old Vic "responsible for the policy of plays and the standard of production, and the Arts Council for managing the theatre", the theatre's Director and Resident Manager were supposed to be seen as "the servants of the Old Vic Company and the Arts Council" (UoB Theatre Collection 1946b). Yet archived correspondence demonstrates the extent to which its Directors continued to remake the theatre in their own image. Appointed in 1946, Hunt particularly was fundamental in advancing Bristol Old Vic's identity as a home for high-quality theatre, cautioning the Arts Council and Old Vic repeatedly about the dangers of lowering "standards", and beseeching audiences for continued support (UoB Theatre Collection 1947a). In fact, between 1946 and 1949 Hunt's own reputation for excellence was deliberately mobilised to solidify the institution's emergent persona: such as when a press release in Theatre Notes called on audiences to realise their "enormous good fortune - which is quite unequaled in the provinces - in having Mr. Hugh Hunt as a producer for this company" (UoB Theatre Collection 1947b).

Here once more, Hunt's personal reputation as an up-and-coming theatre producer who "ranks, in our opinion, with the first six in England" (UoB Theatre Collection 1947b) was used to bolster the formation of the company's desired institutional persona. In turn, Hugh's own reputation was augmented by this partnership to such a degree that, by 1950 , he was able to segue from Bristol Old Vic into the Directorship of its London counterpart. For a working theatre, then, the preservation of an iconic building alone is not enough to sustain audience support; nor is the reputation of its organisation. The institutional persona of a theatre must be constantly maintained through the agency of individuals, working (for the most part) together toward the same aim.

\section{How Do AudienCEs ExPERIENCE THE THEATRE InSTITUTION AS A COMPOSITE PERSONA?}

With the early assistance of the Old Vic and the ongoing support of the Arts Council of England, Farjeon's (and his successors') efforts continued to build on the theatre's growing reputation as an important historical landmark and the home for forward-thinking theatre combined. These connected factors have thus been carried forward into the organisation's contemporary persona. Today, Bristol Old Vic's mission statement is to produce "pioneering" and "world class" "twenty-first-century theatre [...] inspired by the history and magical design of the most 
beautiful playhouse in the country" (Bristol Old Vic 2019b), culminating in the 2018 unveiling of the theatre's new identity as a "heritage visitor attraction" (Bowie-Sell 2018). A $£ 2.4$ million grant from the Heritage Lottery Foundation supported the redevelopment of a brand new foyer that has exposed the original front wall of the building for the first time since 1746, fused old architecture with new, and turned this working theatre into a heritage site: one where augmented reality technology, history tours, and exhibitions are featured alongside the ongoing workings of live performance production.

Bringing together audience discourse from the archives with interviews, questionnaires, and focus groups conducted with audiences today, my research has tracked the 'trajectory of value' from past to present.iv Studying audience engagement from past to present has identified the extent to which, for many local audience members, Bristol Old Vic's international prestige has been and still is a major source of pride. In my post-show surveys audiences have written about how "lucky" they felt "to have such a respected theatre with a reputation for innovation in our home city" [TtV 145], and praising the shows themselves for always being of "the highest quality" [TCO 203]. Importantly, here the quality of performances is often discursively intertwined with the qualities of the architecture - with its productions seen as "relentlessly gripping and entertaining, performed in a building that is steeped in theatre" [TtV 22], and the institution itself having "retained its historical building [while bringing] modern theatrical productions to its stage" [TN 392]. This pleasure in aesthetic excellence can be traced back through the years via letters sent to the theatre's producers, such as these from the $1950 \mathrm{~s}$ addressed to the Director Denis Carey:

The cast rose magnificently to their chances; I can't recall seeing such all-round excellence even at the Bristol Old Vic - a theatre I rank with Stratford or Waterloo. (UoB Theatre Collection 1951)

I feel I must write for myself and many others who went to the Old Vic, Bristol, to see this work of one of our finest writers. The atmosphere of unsolvable tragedy was wonderfully conveyed - the production and acting up to the best standards. [...] We could do with more plays of this high calibre in Bath. (UoB Theatre Collection 1953)

What does all this tell us about how the institutional persona operates for audiences? In recent years we have seen a plethora of institutional studies scholarship investigating the rise in "brand personification" exercises (Levesque 2016, p. 75): a phenomenon which has afforded customers the peculiar experience of comforting a soft drink (Norcia 2019), or watching an iconic American snack-food wish happy birthday to a cat (Sacks 2017). So what is the difference between a theatre company and a corporate organisation like Apple, ${ }^{\mathrm{v}}$ which has similarly developed a distinct institutional persona in order to make its products more appealing? First, the social institution of the arts is very different to that of, say, technology, with the cultural industries experiencing significant tensions between an austerity-accelerated need to engage in neoliberal branding activities and impact assessments, and widespread concerns about the ethical and aesthetic consequences of doing so (Sedgman 2019). And second, unlike other corporate entities, the cultural value of a 'theatre institution' can also be connected to its role as a physical space - not a private office building but a place built for community congregation.

As public buildings, then, theatres have always been public-facing; their directors and performers have always to some extent acted as public extensions of the institutional self. The institutional persona is not the product of the contemporary era alone, but has needed to undergo constant reinventions over time. These constellations are dynamic and subject to flux: firstly, because of the changing cast of individuals responsible for securing and maintaining an institution's identity (e.g. artistic directors, producers, patrons, actors, playwrights, directors, 
and designers); secondly, because of the need to negotiate the shifting historical and cultural frameworks in which these networks are embedded. Theatre is therefore an ideal example of the composite persona: one in which institutional relationships may be shaped by audiences' connections with theatres as organisations/brands/commercial entities, or by their engagements with landmark buildings, or by their encounters with specific personnel - or, more likely, by all of the above at once.

\section{CONCLUSION}

In recent years, Bristol Old Vic, like many theatres in England, has continued to weather a series of civic crises, subjected especially to the ebb-and-flow of both centralised and city council funding. These events have continued to feed into the theatre's narrative of survival and renewal that has been crucial for the city itself. Most recently, in 2007, the Arts Council was "accused of forcing the Bristol Old Vic board into its forthcoming closure of the theatre and the departure of [its] artistic director Simon Reade". The shock decision was officially attributed to a building survey, which identified the need for urgent work "to keep it in line with health and safety standards", but was also likely connected to recent financial losses: with certain productions having "failed to bring in the required box office [...] [by the end of that] financial year, the venue had a deficit of around $£ 160,000$ " (Smith 2007). As an anonymous source at the time commented: "A theatre without an artistic director is [...] just a building", lacking "a vision" (qtd in Smith 2007) - or even its persona. Hence, having been saved once again from the brink by a dedicated campaign - this time spearheaded by the local director of Bristol's Watershed Media Centre, Dick Penny - the theatre's revival was secured in 2009 by the joint intervention of Artistic Director Tom Morris (fresh from his success on the National Theatre's smash-hit War Horse) and Executive Director, Emma Stenning.

As I have argued, the institution's historical persona built on its prestigious architectural heritage combined with its reputation for progressive aesthetic prowess. Morris and Stenning's tenure continued that tradition, with the theatre's marketing materials consistently emphasising the building's history as a "symbol of the pride we have in our city" and its desire to remain "a place of joy, discovery and adventure to this day" (Bristol Old Vic 2019a). The theatre's reputation has been further re-solidified in recent years through its associations with key contemporary theatre-makers, most notably the Cornish company Kneehigh and the Bristol-based director Sally Cookson, the latter of whose Bristol Old Vic productions of Treasure Island (2011), Peter Pan (2012), and Jane Eyre (2015) have all had prominent afterlives in London. For some audiences, these external organisations and practitioners are inextricable from pleasure taken in Bristol Old Vic itself:

To my great shame I had not seen anything at BOV until Jane Eyre in 2016. I fell in love with Sally Cookson's work, the theatre, the atmosphere and the BOV experience. [TtV 407]

I have seen some really excellent (and at least one truly awful) productions here. I love the Kneehigh productions (shame they couldn't have brought their joint production in this summer it sounded fab). [TN 367]

Paying attention to theatre demonstrates how the strategic production of an institutional persona over time intersects in complex ways with the changing individual personas who inhabit its building: the constant flow of Artistic Directors, actors, directors, writers, and performance companies, each of whom may bring with them their own distinct celebrities and associated audiences. The case of the Bristol Old Vic demonstrates the importance of considering how these spectatorial engagements are shaped between the interwoven layers of 
the institutional persona; by the physical structure of the theatre building as well as the reputation of its organisation; and also by the particular performance traditions and histories valued by the people whom it houses over time.

In order to understand the institutional persona in all its rich complexity, though, we need to understand not just the machinations that have gone into producing it, but also how that performance of self has been received. For some audiences, the Bristol Old Vic is primarily a beautiful and historic building, a local landmark with national importance of which they can justly feel proud. For others, it is predominantly a forward-facing, world-leading producer and supporter of high-quality aesthetic experience. But more often, the cultural value of Bristol Old Vic is understood as produced via a combination of these factors - as a prestigious collision of place, performance, and people.

If the value of Persona Studies lies, in part, in the examination of how an individual moves into social spaces and presents the self via those four dimensions - value, agency, reputation, and prestige - then there is a value too in understanding how institutions do the same. In the case of a composite persona like Bristol Old Vic, the institution's prestige has been secured over time through its promulgation of a centralised, classist model of aesthetic value and its assertion of architectural reputation: as the "longest continuously-running theatre in the English-speaking world". This process relies on the agentic involvements of individuals within the institutional persona. In order to survive, an institution like Bristol Old Vic has had simultaneously to present itself as historic and forward-looking, as theatre building and performance event - a public presentation of self that requires constant redefinitions. In order to ensure survival, theatres have needed to learn how to tell good stories not only on their stages but also about themselves.

\section{ACKNOWLEDGEMENTS}

The author would like to acknowledge the support of staff at the University of Bristol Theatre Collection in the writing of this essay, as well Mary Luckhurst and Sandra Mayer for their insightful and inspiring editorial advice. This article was made possible by the British Academy, who funded the research through their Postdoctoral Fellowship scheme.

\section{END NOTES}

i In fact, Vessey notes that "the classical sense of 'profession'" itself has been built through the construction of "the quasi-institutional, persona-forming authority of famous historical exemplars" (2012, p. 240). This process of professionalization through commodification explains why it is people in poverty who over the centuries have been left to "survive as individuals with no institutional persona" (Sobhan 2006, p. 325).

ii By 1819 the city's Hotwells had fallen totally out of favour, followed shortly afterwards by the 1838 abolition of the Bristol's popular September Fair.

iii Following their 1960s split from Old Vic the theatre retained its name, which means the building itself has gradually over the years shifted from being known by locals as the Theatre Royal to being specifically branded as Bristol Old Vic, its performances marked with the qualitystamp of a 'Bristol Old Vic production'. 
iv Here I deploy the principle of 'heavy disguise' (Bruckman 2002) rather than a traditional reference format, using a unique ID to provide respondents with anonymity whilst at the same time enabling the interested reader to track audience discourse across multiple publications. TCO refers to the Bristol Old Vic production of The Cherry Orchard (March 2018), TtV to Touching the Void (September 2018), and TN to Twelfth Night (October 2018).

v A company mythology that has notably been built on the individual persona of its founder, Steve Jobs.

\section{WORKS CITED}

Arnold, M. 2006 [1869], Culture and Anarchy, Oxford University Press, Oxford.

Barker, K. 1966, The Theatre Royal, Bristol: Decline and Rebirth, 1834-1943, Bristol Branch of the Historical Association, no. 14.

Barker, K. 1974, The Theatre Royal, Bristol, 1766-1966: Two Centuries of Stage History, Society for Theatre Research, London.

Bice, S. 2017, 'Corporate Social Responsibility as Institution: A Social Mechanisms Framework', Journal of Business Ethics, vol. 143, no. 1, pp. 17-34.

Bowie-Sell, D. 2018, 'Bristol Old Vic transformed', WhatsOnStage website 24 September,

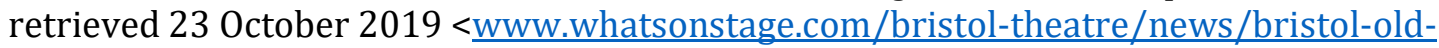
vic-new-building-opens-2018 47657.html>

Bristol Old Vic 2019a, 'Heritage', Bristol Old Vic website, retrieved 23 October 2019 $<$ https://bristololdvic.org.uk/heritage>

-2019b, 'Our Story', Bristol Old Vic website, retrieved 23 October 2019 $<$ https://bristololdvic.org.uk/about/our-story>

Bruckman, A. 2002, 'Ethical Guidelines for Research Online', Georgia Institute of Technology, retrieved 23 October 2019 <http://www.cc.gatech.edu/ asb/ethics>

Bucknall, J \& Sedgman, K. 2017, 'Documenting Audience Experience: Social Media as Lively Stratification', in T. Sant (ed.) Documenting Performance: The Context and Processes of Digital Curation \& Archiving, Bloomsbury Methuen Drama, London, pp. 113-130.

Campbell, J. L. \& Pedersen, O. K. (eds) 2001, The Rise of Neoliberalism and Institutional Analysis, Princeton University Press, Princeton.

DeHart, M. 2009, 'Fried Chicken or Pop? Redefining Development and Ethnicity in Totonicapán', Bulletin of Latin American Research, vol. 28, no. 1, pp. 63-82.

Desta, Y. 2017, 'Multiple Shakespearean Theaters Are Getting Death Threats After New York's Trump-Inspired Julius Caesar', Vanity Fair, 19 June, retrieved 23 October 2019 <www.vanityfair.com/hollywood/2017/06/trump-julius-caesar-death-threats>

Dexus Property Group 2019, 'The Show Goes On for Sydney's Theatre Royal', The Urban Developer, 18 March, retrieved 23 October 2019 $<$ https://theurbandeveloper.com/articles/the-show-goes-on-for-sydneys-theatreroyal>

Eide, M. \& Siøvaag, H. 2016, 'Journalism as an Institution', in M. Eide (ed.) Journalism ReExamined: Digital Challenges and Professional Orientations (Lessons from Northern Europe), University of Chicago Press, Chicago, pp. 3-14.

Forgan, S. 1986, 'Context, Image and Function: A Preliminary Enquiry into the Architecture of Scientific Societies', The British Journal for the History of Science, vol. 19, no. 1, pp. 89113.

Georgian Theatre Royal 2019, 'Join the Friends', The Georgian Theatre Royal website, retrieved 23 October 2019 <http://www.georgiantheatreroyal.co.uk/Support/Friends.aspx>

Herskovitz, S. \& Crystal, M. 2010, 'The Essential Brand Persona: Storytelling and Branding', Journal of Business Strategy, vol. 31, no. 3, pp. 21-28.

Holt, D. B. 2002, 'Why do brands cause trouble? A dialectical theory of consumer culture and branding', Journal of Consumer Research, vol. 29, no. 1, pp. 70-90. 
Hopper, R. et al. 1993, 'Demographic Questions in Telephone Calls to a Cancer Information Service', Southern Journal of Communication, vol. 58, no. 2, pp. 115-127.

ITV 2017, 'Bristol Old Vic reveal time lapse video of major redevelopment', ITV website 26 April, retrieved 23 October $2019<w w w . i t v . c o m / n e w s / w e s t c o u n t r y / 2017-04-26 / w a t c h-$ bristol-old-vic-reveal-time-lapse-video-of-major-redevelopment>

Johnston, H. 2008, 'Moral Guardians? Prison Officers, Prison Practice and Ambiguity in the Nineteenth Century', in H. Johnston (ed.) Punishment and Control in Historical Perspective, Palgrave Macmillan, London, pp. 77-94.

Kent Online 2007, 'Fears for future of historic theatre', Kent Online 23 February, retrieved 23 October $2019<$ www.kentonline.co.uk/kent/news/fears-for-future-of-historic-thea28405>

Lasdun, D. 1977, 'Architectural Aspects of the National Theatre', Journal of the Royal Society of Arts, vol. 125, no. 5256, pp. 780-792.

Leventhal, F. M. 1990, “The Best for the Most": CEMA and State Sponsorship of the Arts in Wartime, 1939-1945', Twentieth Century British History vol. 1, no. 3, pp. 289-317.

Levesque, L. 2016, 'Social Media in Academic Libraries: Engaging in 140 Characters or Less', Public Services Quarterly, vol. 12, no. 1, pp. 71-76.

Marshall, P. D. \& Barbour, K. 2015, 'Making Intellectual Room for Persona Studies', Persona Studies, vol. 1, no. 1, pp. 1-12.

McMullen, T., Maze, J., Michell, J. \& Kennedy, B. 1996. 'Review Symposia', Metascience vol. 5, no. 2, pp. 6-20.

Meyer, J. W. \& Rowan, B. 1977, 'Institutionalized Organizations: Formal Structure as Myth and Ceremony', The American Journal of Sociology, vol. 83, pp. 340-363.

Moore, C., K. Barbour \& K. Lee 2017, 'Five Dimensions of Online Persona', Persona Studies, vol. 3, no. 1, pp. 1-11.

Nao, M. 2011, 'The Pragmatic Realization of the Native Speaking English Teacher as a Monolingual Ideal', Journal of Pragmatics, vol. 43, no. 15, pp. 3770-3781.

Nestruck, J. K. 2018, 'A theatre company without a venue? Yeah, Why Not', The Globe and Mail 16

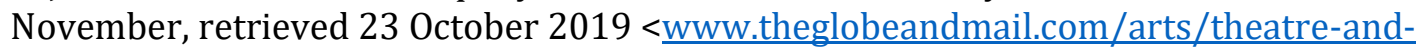
performance/article-a-theatre-company-without-a-venue-yeah-why-not>

Norcia, A. 2019, 'Brand Twitter Is Absurd, and It Will Only Get Worse', VICE website 13 February, retrieved 23 October $2019<$ www.vice.com/en us/article/pangw8/brandtwitter-is-absurd-and-it-will-only-get-worse $>$

Peters, T. 1997, 'The Brand Called You', Fast Company, vol. 10, no. 10, pp. 83-90.

Powell, W. \& DiMaggio, P. 1991, The New Institutionalism in Organizational Analysis, The University of Chicago Press, Chicago.

Rogers, P. 2017, 'Family is NOT an Institution: Distinguishing Institutions from Organisations in Social Science and Social Theory', International Review of Sociology vol. 27, no. 1, pp. 126-141.

Romania Insider 2018, 'Bucharest Centennial: The National Theater, the grand stage of the Romanian culture', Romania Insider website 4 September, retrieved 23 October 2019 $<$ www.romania-insider.com/bucharest-centennial-national-theater-2018>

Sacks, B. 2017, 'This Is Who's Behind MoonPie's Hysterically Weird Twitter Account', Buzzfeed website 18 Dec, retrieved 23 October 2019 $<$ www.buzzfeednews.com/article/briannasacks/the-darkside-of-the-moonpie $>$

Searle, J. R. 2005, 'What is an Institution?', Journal of Institutional Economics, vol. 1, no. 1 pp. 122.

Sedgman, K. 2019, 'Challenges of Cultural Industry Knowledge Exchange in Live Performance Audience Research', Cultural Trends, vol. 28, no. 2-3 pp. 103-117.

Sobhan, R. 2006, 'Poverty as Injustice: Refocusing the Policy Agenda', in J. K. Boyce, K. B. Griffin \& J. K. Boyce (eds.) Human Development in the Era of Globalization: Essays in Honor of Keith B. Griffin, Edward Elgar Publishing, Cheltenham, pp. 325-343. 
Smith, A. 2007, 'ACE blamed for shock Bristol Old Vic closure', The Stage website 16 May, retrieved 23 October $2019<w w w . t h e s t a g e . c o . u k / n e w s / 2007 /$ ace-blamed-for-shockbristol-old-vic-closure>

Smith, D. 2019, 'A Role for Theatre in Criminal Justice?', American Theatre 22 January, retrieved 23 October $2019<$ www.americantheatre.org/2019/01/22/a-role-for-theatre-incriminal-justice>

Speed, R. et al. 2015, 'Human Branding in Political Marketing: Applying Contemporary Branding Thought to Political Parties and their Leaders', Journal of Political Marketing, vol. 14, no. 1-2, pp. 129-151.

Thompson, J. 2018, 'Old Vic Theatre celebrates 200th birthday: 7 fascinating things you never knew', The Standard 10 May, retrieved 23 October 2019 $<$ https://www.standard.co.uk/go/london/theatre/old-vic-theatre-celebrates-200thbirthday-7-fascinating-things-you-never-knew-a3835981.html>

Tolbert, P. S. \& Coles, R. 2018, 'Studying Entrepreneurship as an Institution', in J. Glückler, R. Suddaby \& R. Lenz (eds.) Knowledge and Institutions, Springer, Cham, pp. 271-299.

Toppman, L. 2018, 'A Charlotte (theater) institution: Billy Ensley as actor, director, collaborative pro', Charlotte Observer 15 May, retrieved 23 October 2019 $<$ www.charlotteobserver.com/entertainment/arts-culture/article211199754.html>

University of Bristol Theatre Collection 1935a, letter from Herbert Farjeon to Milton Bode (circa 29 May 1935), HF/BOV/C/000003/1.

-1935b, letter from Herbert Farjeon to Milton Bode (3 July 1935), HF/BOV/C/000007/2.

-1942, letter from Herbert Farjeon to The Times newspaper (14 January 1942), $\mathrm{HF} / \mathrm{BOV} / \mathrm{C} / 000012 / 1$.

—1943, 'England's Oldest Theatre' by Herbert Farjeon, HF/BOV/PS/000003.

—1946a, minutes from Theatre Royal Committee meeting (17 July 1946), BOV/MIN/000001.

-1946b, minutes from Theatre Royal Management Committee meeting (22 October 1946), Box 291.

—1947a, Hugh Hunt's column, Bristol Old Vic Theatre Club Newsletter (11 March 1947), Box 530.

-1947b, 'The Second Season', Theatre Notes (April 1947), Box 291.

—1949, Old Vic Annual Reports for Season 1948-1949, OV/F/000038.

-1951, letter from audience member to Bristol Old Vic (4 November 1951), KS/BOV/195111/AC1.

-1953, letter from audience member to Bristol Old Vic (6 April 1953), KS/BOV/195304/AC1.

Vessey, M. 2012, 'Augustine among the Writers of the Church', in M. Vessey (ed.) A Companion to Augustine, Wiley Blackwell, Oxford, pp. 240-254.

Wood, A. 2018, 'Tyrone Huntley, Ria Jones and Ben Forster to star in Andrew Lloyd Webber biography musical workshop', WhatsOnStage website 26 October, retrieved 23 October $2019<$ www.whatsonstage.com/london-theatre/news/tyrone-huntley-ria-jones-lloydwebber-unmasked 47902.html>

York Theatre Royal 2019, 'Support Us', York Theatre Royal website, retrieved 23 October 2019 <https://www.yorktheatreroyal.co.uk/page/support us.php> 